\title{
Combination of quercetin and hyperoside has anticancer effects on renal cancer cells through inhibition of oncogenic microRNA-27a
}

\author{
WEI LI ${ }^{1 *}$, MIN LIU $^{1 *}$, YUN-FEI XU ${ }^{1 *}$, YUAN FENG ${ }^{2}$, JIAN-PING CHE $^{1}$, \\ GUANG-CHUN WANG ${ }^{1}$ and JUN-HUA ZHENG ${ }^{1}$ \\ ${ }^{1}$ Department of Urology, Shanghai Tenth People's Hospital, Tongji University, Shanghai 200072; \\ ${ }^{2}$ Department of Nephrology, Affiliated Drum Tower Hospital of Nanjing University, \\ Nanjing, Jiangsu 210093, P.R. China
}

Received September 5, 2013; Accepted October 7, 2013

DOI: 10.3892/or.2013.2811

\begin{abstract}
Quercetin and hyperoside $(\mathrm{QH})$ in combination (1:1 ratio) have previously been shown to inhibit the growth of human leukemia cells. Here, we investigated the anticancer activity of the same mixture in 786-O renal cancer cells. QH decreased the generation of reactive oxygen species (ROS) by up to 2.25-fold and increased the antioxidant capacity by up to 3 -fold in $786-\mathrm{O}$ cells $(3.8-60 \mu \mathrm{g} / \mathrm{ml})$, whereas $\mathrm{IC}_{50}$ values for viability were $18.2,18.7$ and $11.8 \mu \mathrm{g} / \mathrm{ml}$, respectively. QH also induced caspase-3 cleavage (2-fold) and increased PARP cleavage. Specificity protein ( $\mathrm{Sp}$ ) transcription factors are overexpressed in cancer cells and regulate genes required for cell proliferation, survival and angiogenesis. QH treatment decreased the expression of Sp1, Sp3 and Sp4 mRNA and this was accompanied by decreased protein expression. Moreover, expression of the Sp-dependent anti-apoptotic survival gene survivin was also significantly reduced, both at the mRNA and protein levels. QH decreased microRNA-27a (miR-27a) and induced the zinc finger protein ZBTB10, an Sp-repressor, suggesting that interactions between $\mathrm{QH}$ and the miR-27a-ZBTB10 axis play a role in Sp downregulation. This was confirmed by transfection of cells with a specific mimic for miR-27a, which partially reversed the effects of QH. These findings are consistent with previous studies on botanical anticancer agents in colon cancer cells.
\end{abstract}

\section{Introduction}

Renal cell carcinoma (RCC) is the most lethal urologic tumor and the sixth leading cause of cancer-related mortality in

Correspondence to: Professor Jun-Hua Zheng, Department of Urology, Shanghai Tenth People's Hospital, Tongji University, 301 Yanchang Road, Shanghai 200072, P.R. China

E-mail: kidneyliu@163.com

*Contributed equally

Key words: renal cancer, quercetin, hyperoside, microRNA-27a
Western countries. Each year, approximately 200,000 patients are diagnosed with this malignancy resulting in approximately 100,000 deaths, and its incidence has steadily increased in the last decades (1-3). At present, the most effective treatment for localized RCC is surgical resection; however, $30 \%$ of patients develop metastatic disease after surgery, and the median survival for these patients is only 13 months. Therefore, novel therapeutic strategy as well as prophylactic regimens are urgently required.

Prevention of numerous types of cancer through a diet rich in fruits and vegetables has been in part attributed to plant-derived botanicals, including polyphenolics, which may protect against various chronic degenerative diseases such as cancer or cardiovascular disease (4). Quercetin is a dietary flavonoid found in tea, onion, grapes, wines and apples, and the anticancer activities of quercetin have been assessed in several cancer cell lines, as well as in vivo $(5,6)$. Hyperoside is a stilbene analog and a phytoalexin produced by plants as a defense mechanism in response to fungal diseases, stress and UV radiation; the primary dietary sources of hyperoside are Malus micromalus and abelmosk (7). Hyperoside was found to exhibit anticancer properties by inhibiting cell proliferation, inducing apoptosis, decreasing angiogenesis, and causing cell cycle arrest in several cancer cell lines (8). A combination of quercetin and hyperoside $(\mathrm{QH})$ previously exhibited synergistic interactions in their anticancer effects on MOLT-4 leukemia cells (9). In a study with mouse skin tumors, a combination of hyperoside with tea polyphenolics demonstrated synergistic anticancer effects (10). In pancreatic cancer stem cells, sulforaphane was found to synergize with quercetin in the inhibition of the self-renewal of cells (11). Quercetin and epigallocatechin gallate (EGCG) synergistically inhibited invasion, migration and epithelial-mesenchymal transition in prostate cancer stem cells (12).

Increasing evidence suggests that specificity protein $(\mathrm{Sp})$ transcription factors Sp1, Sp3 and Sp4 are overexpressed in tumors and regulate genes important for cancer cell death and survival $(13,14)$. More recently, the involvement of microRNA-27a (miR-27a) in the regulation of Sp1 transcription factor through zinc finger protein ZBTB10, an inhibitor of Sp1, 
has been demonstrated. Additionally, botanical compounds were also found to inhibit Sp transcription factors through the miR-27a-ZBTB10-Sp1 axis (15-17). Therefore, the aim of this study was to investigate the effects of a mixture of quercetin and hyperoside on Sp1, Sp3 and Sp4 expression and the potential involvement of miR-27a in the downregulation of $\mathrm{Sp}$ transcription factors in 786-O renal cell carcinoma cells.

\section{Materials and methods}

Botanical extract. Polyphenolics were extracted from a standardized QH dehydrate supplement (ratio 1:1) in capsule form which was provided by Suzhong Pharmaceutical Co., Ltd. (Taizhou, Jiangsu, China). Polyphenolics were extracted with methanol $(50 \mathrm{mg} / 50 \mathrm{ml})$ and then centrifuged at room temperature for $10 \mathrm{~min}$ at $3,000 \mathrm{rpm}$ to remove inactive and insoluble components. Methanol was evaporated in a rotavapor (BÜCHI Labortechnik AG, Flawil, Switzerland) at $40^{\circ} \mathrm{C}$. Residual moisture was evaporated in a speedvac concentrator (Thermo Scientific, Waltham, MA, USA) at $43^{\circ} \mathrm{C}$. The final $\mathrm{QH}$ mixture was stored at $-80^{\circ} \mathrm{C}$ and dissolved in dimethyl sulfoxide (DMSO) prior to use.

HPLC-PDA analysis. The polyphenolic mixture was analyzed and quantified by retention time and photodiode array (PDA) spectra by HPLC-PDA. The chromatographic separation was performed in an Alliance 2695 system (Waters Corporation, Milford, MA, USA) and carried out in a Discovery C18 column (Supelco Inc., Bellefonte, PA, USA) $(250 \times 4.6 \mathrm{~mm}$, $5 \mu \mathrm{m})$ at room temperature. The chromatographic conditions used were mobile phase A: water/acetic acid (98:2), mobile phase B: acetonitrile/water/acetic acid (68:30:2). A gradient program with $1 \mathrm{ml} / \mathrm{min}$ was used as follows: $0 \mathrm{~min} 100 \%, \mathrm{~A}$; $20 \min 60 \%, \mathrm{~A} ; 30 \mathrm{~min} 30 \%$, A; $32 \mathrm{~min} 0 \%$, A; $35 \mathrm{~min} 100 \%$, A. The detection wavelengths were set at 360 and $306 \mathrm{~nm}$ for quercetin and hyperoside, respectively. Standard compounds for the identification and quantitative analysis of quercetin and hyperoside were obtained from Acros Organics (Morris Plains, NJ, USA).

Oxygen radical absorbance capacity. The antioxidant capacity was determined using the oxygen radical absorbance capacity assay (ORAC) (22) with fluorescein as the fluorescent probe in a FLUOstar fluorescence microplate reader (485 $\mathrm{nm}$ excitation and 538 nm emission; BMG Labtech Inc., Durham, NC, USA). Results were reported in $\mu \mathrm{mol}$ of Trolox equivalents $/ \mathrm{ml}$.

Cell culture. Human clear cell renal carcinoma 786-O cells [American Type Culture Collection (ATCC), Manassas, VA, USA] were cultured in Mc-Coy's medium supplemented with $10 \%$ fetal bovine serum (FBS) and 1\% antibiotics (100,000 U/1 penicillin and $100 \mathrm{mg} / \mathrm{l}$ streptomycin). Cells were maintained in a humidified atmosphere of $95 \%$ air and $5 \% \mathrm{CO}_{2}$ at $37^{\circ} \mathrm{C}$. For experiments, cells were seeded in DMEM/F-12 medium with $2.5 \% \mathrm{FBS}$, and $1 \%$ antibiotics $(100,000 \mathrm{U} / 1$ penicillin and $100 \mathrm{mg} / \mathrm{l}$ streptomycin). Generation of reactive oxygen species (ROS) was determined using the 2',7'-dichlorofluorescein diacetate (DCFH-DA) assay. In summary, $1 \times 10^{4}$ cells/well were seeded in a clear bottom 96-well plate and incubated for $24 \mathrm{~h}$, and then treated with different concentrations of
QH $(0-60 \mu \mathrm{g} / \mathrm{ml})$. After $24 \mathrm{~h}$, cells were washed twice with phosphate-buffered saline (PBS) and incubated with $200 \mu \mathrm{M}$ hydrogen peroxide for $2 \mathrm{~h}$ at $37^{\circ} \mathrm{C}$. Hydrogen peroxide was removed with PBS washes, and $10 \mu \mathrm{M}$ DCFH-DA diluted in PBS was added to the cells. Next, cells were incubated for $15 \mathrm{~min}$ at $37^{\circ} \mathrm{C}$, DCFH-DA was removed, and the fluorescence intensity was measured after $15 \mathrm{~min}$ at $37^{\circ} \mathrm{C}$ using a FLUOstar fluorescent microplate reader $(485 \mathrm{~nm}$ excitation and $538 \mathrm{~nm}$ emission).

Cell viability. Cells were seeded $\left(3 \times 10^{3}\right.$ cells/well) in a 96-well plate for $24 \mathrm{~h}$, and the growth medium was then replaced with the experimental medium containing various extract concentrations of QH $(0-60 \mu \mathrm{g} / \mathrm{ml})$. Cell viability was assessed at 48 , 72 and $96 \mathrm{~h}$ with the CellTiter $96^{\circledR}$ AQueous One Solution Cell Proliferation assay (Promega, Madison, WI, USA) according to the manufacturer's protocol using a FLUOstar microplate reader at $490 \mathrm{~nm}$. The concentration at which cell viability was inhibited by $50 \%\left(\mathrm{IC}_{50}\right)$ was calculated by sigmoidal nonlinear regression analyses of the percentage of cell inhibition, expressed as a ratio to the control, using GraphPad Prism 5.01 software (GraphPad Software Inc., La Jolla, CA, USA).

Cell proliferation. $786-\mathrm{O}$ cells $\left(2 \times 10^{4}\right.$ cells/well $)$ were grown in a 24 -well plate for $24 \mathrm{~h}$. The growth medium was then replaced with experimental medium containing $\mathrm{QH}$ extract concentrations ranging from 0 to $60 \mu \mathrm{g} / \mathrm{ml}$. After $72 \mathrm{~h}$ cell proliferation was determined using a cell counter (Beckman Coulter Inc., Fullerton, CA, USA). Cell counts were expressed as a percentage of the control cells.

Cleaved caspase-3 activation. Cells were grown $\left(6 \times 10^{5}\right.$ cells/well) for $24 \mathrm{~h}$ and then incubated with different $\mathrm{QH}$ concentrations $(0-30 \mu \mathrm{g} / \mathrm{ml})$ for $24 \mathrm{~h}$. Cleaved caspase-3 activation was determined using an ELISA kit (Cell Signaling Technology Inc., Danvers, MA, USA) according to the manufacturer's protocol using a FLUOstar microplate reader at $450 \mathrm{~nm}$.

Real-time PCR analysis of miRNA and mRNA. 786-O cells were grown $\left(2 \times 10^{5}\right.$ cells/well) in a 6 -well plate for $24 \mathrm{~h}$ before incubation with different concentrations of QH $(0-30 \mu \mathrm{g} / \mathrm{ml})$. Total RNA, which contains both mRNA and miRNA, was isolated using the mirVana ${ }^{\mathrm{TM}}$ miRNA Isolation kit (Applied Biosystems Inc., Foster City, CA, USA) following the manufacturer's recommended protocol. Extracted nucleic acid was evaluated for quality and quantity using the NanoDrop ${ }^{\circledR}$ ND-1000 Spectrophotometer (NanoDrop Technologies, Wilmington, DE, USA) at 260 and $280 \mathrm{~nm}$.

SuperScript $^{\text {TM }}$ III First-Strand (Invitrogen, Carlsbad, CA, USA) was used to reverse-transcribe mRNA. TATA-binding protein (TPB) was used as an mRNA endogenous control. For real time PCR (RT-PCR), proprietary primers for Sp3 and Sp4 (Qiagen Inc., Valencia, CA, USA) were used. The following primers were purchased from Integrated DNA Technologies, Inc. (Coralville, IA, USA) and used for amplification as follows: TBP (sense, 5'-TGC ACA GGA GCC AAG AGT GAA-3' and antisense, 5'-CAC ATC ACA GCT CCC CAC CA-3'), caspase-3 (sense, 5'-CTG GAC TGT GGC ATT GAG ACA-3' and antisense, 5'-CGG CCT CCA CTG GTA TTT 
TAT G-3'), ZBTB10 (sense, 5'-GCT GGA TAG TAG TTA TGT TGC-3' and antisense, 5'-CTG AGT GGT TTG ATG GAC AGA G-3'), Spl (sense, 5'-TCA CCA ATG CCA ATA GCT ACT CA-3' and antisense, 5'-GAG TTG GTC CCT GAT GAT CCA-3'), survivin (sense, 5'-CCA TGC AAA GGA AAC CAA CAA T-3' and antisense, 5'-ATG GCA CGG CGC ACT T-3'). RT-PCR for mRNA was performed using the SYBR GreenER qPCR SuperMix (Invitrogen) on a 7900HT Fast Real-Time PCR System (Applied Biosystems Inc.).

The TaqMan ${ }^{\circledR}$ MicroRNA Assay for miR-27a and RNU6B (used as the control; Applied Biosystems Inc.) was used to reverse-transcribe mature miRNA following the manufacturer's protocol in a MasterCycler (Eppendorf North America Inc., Westbury, NY, USA). RT-PCR for miRNA was carried out with the TaqMan ${ }^{\circledR}$ assay, which contained the forward and reverse primers as well as the TaqMan ${ }^{\circledR}$ probe and TaqMan ${ }^{\circledR}$ Universal PCR Master mix, No AmpErase ${ }^{\circledR}$ UNG (Applied Biosystems Inc.). After completion of RT-PCR, relative quantification for both mRNA and miRNA gene expression was evaluated by using the comparative critical threshold (CT) method. Transfections with 50 and $100 \mathrm{nM}$ miR-27a mimic (Dharmacon, Lafayette, CO, USA) were performed using Lipofectamine 2000 (Invitrogen) for $6 \mathrm{~h}$. After transfection, cells were incubated with $20 \mu \mathrm{g} / \mathrm{ml}$ of $\mathrm{QH}$ for $24 \mathrm{~h}$.

Cell cycle kinetics. Cells were seeded $\left(5 \times 10^{5}\right.$ cells/plate) with medium containing $2.5 \%$ FBS for $24 \mathrm{~h}$ and were subsequently treated with QH $(0-20 \mu \mathrm{g} / \mathrm{ml})$ for $24 \mathrm{~h}$. Cells were fixed with $90 \%$ ethanol and stored at $-20^{\circ} \mathrm{C}$. DNA was stained with propidium iodide containing RNAse $(0.2 \mathrm{mg} / \mathrm{ml})$ solution and analysis was carried out at $488 \mathrm{~nm}$ excitation and $620 \mathrm{~nm}$ emission wavelengths on a FACScan flow cytometer (BD Immonunocytometry Systems, San José, CA, USA). The percentage of cells in each cell cycle phase was analyzed using the ModFit LT version 3.2 for Macintosh by Verity Software House (Topsham, ME, USA).

Western blotting. Cells were grown $\left(2 \times 10^{6}\right.$ cells/plate $)$ for $24 \mathrm{~h}$ and treated with $\mathrm{QH}(0-30 \mu \mathrm{g} / \mathrm{ml})$ for $24 \mathrm{~h}$. Cells were harvested and cell lysates were obtained using a high-salt buffer $\left(1.5 \mathrm{mmol} / 1 \mathrm{MgCl}_{2}, 500 \mathrm{mmol} / 1 \mathrm{NaCl}, 1 \mathrm{mmol} / 1 \mathrm{EGTA}\right.$, $50 \mathrm{mmol} / 1 \mathrm{HEPES}, 10 \%$ glycerol, $1 \%$ Triton X-100; adjusted to pH 7.5) supplemented with protease inhibitors (Sigma-Aldrich, St. Louis, MO, USA). Samples were incubated at $100^{\circ} \mathrm{C}$ for $5 \mathrm{~min}$ in $1 \mathrm{X}$ Laemmli buffer $(0.1 \%$ bromophenol blue, $175 \mathrm{mM}$ $\beta$-mercaptoethanol, $50 \mathrm{mM}$ Tris- $\mathrm{HCl}, 2 \% \mathrm{SDS}$ ). Proteins were separated on a $10 \%$ (Sp proteins) or $12 \%$ (survivin) SDS-PAGE at $100 \mathrm{~V}$ and transferred to PVDF membranes (Bio-Rad, Hercules, CA, USA). Membranes were blocked in nonfat milk in PBS-Tween and incubated with primary antibodies overnight at $4^{\circ} \mathrm{C}$. After multiple washing steps, membranes were incubated with secondary antibodies. Membranes were washed and incubated with chemiluminescence substrate (Santa Cruz Biotechnology, Inc., Santa Cruz, CA, USA), and proteins were visualized with a Kodak Molecular Imaging System (Carestream Health Inc., Rochester, NY, USA).

Statistical analyses. Data from the in vitro experiments were analyzed by one-way analysis of variance with JMP 8.0 (SAS Institute, Cary, NC, USA). Differences were deemed significant at $\mathrm{p} \leq 0.05$ using a Tukey-Cramer HSD comparison for all pairs. For transfections with the miR-27a mimic, differences were deemed significant at $\mathrm{p} \leq 0.05$ using a Student's t-test comparison for all pairs. The analysis of linear (pairwise) correlations was performed where correlations with a p-value $<0.05$ were deemed significant. Nonlinear modeling of sigmoidal curves for cell viability was performed using GraphPad Prism 5.01 software (GraphPad Software Inc.).

\section{Results}

Chemical composition. The chromatographic profiles (Fig. 1A and $\mathrm{B}$ ) of $\mathrm{QH}$ demonstrated the presence of 2 major polyphenols, hyperoside (peak 1) and quercetin (peak 2), respectively, as major ingredients of this botanical supplement. The chemical structures of quercetin and hyperoside are listed in Fig. 1C and D. In fact, both quercetin and hyperoside are among the most abundant flavonoids in the routine human $\operatorname{diet}(4,18)$.

Generation of intracellular ROS and ORAC. Intracellular generation of ROS was investigated after 786-O cells were challenged with hydrogen peroxide. QH slightly induced the generation of ROS at low concentrations $(0-10 \mu \mathrm{g} / \mathrm{ml})$ whereas at concentrations $>20 \mu \mathrm{g} / \mathrm{ml}$, generation of ROS was significantly reduced (Fig. 1E) by up to $66 \%$ compared to that of solvent-treated control cells. The antioxidant capacity values (ORAC) (Fig. 1F), were significantly increased by all concentrations of $\mathrm{QH}$ in a dose-dependent manner.

Cell death and cell cycle kinetics. 786-O cell viability (Fig. 2A) was significantly decreased by $\mathrm{QH}$ in a dose- and time-dependent manner. The $\mathrm{IC}_{50}$ values were $18.2,18.7$ and $11.8 \mu \mathrm{g} / \mathrm{ml}$ at 48,72 and $96 \mathrm{~h}$, respectively. QH also inhibited cell proliferation after treatment for $72 \mathrm{~h}$ (Fig. 2B) illustrated by a decrease in cell counts in a dose-dependent manner. The net number of cells remaining was the combined results of cancer cell proliferation as well as the cytotoxicity of QH. Cell numbers were significantly decreased at all concentrations (3.75-60 $\mu \mathrm{g} / \mathrm{ml})$, and at $60 \mu \mathrm{g} / \mathrm{ml} \mathrm{QH}$ cell proliferation was reduced by up to $73 \%$.

The effects of $\mathrm{QH}$ on cell-cycle progression were determined by fluorescence-activated cell sorting (FACS) analysis (Fig. 2C). There were minor but significant changes in the percentage of cells in different phases of the cell cycle using $2.5,5$, or $10 \mu \mathrm{g} / \mathrm{ml}$ of extract. There was a significant $\mathrm{G}_{0} / \mathrm{G}_{1}$ to S-phase arrest when compared to the control cells when cells were treated with $20 \mu \mathrm{g} / \mathrm{ml}$ of the mixture (Fig. 2C).

Cleaved caspase- 3 , the activated form, is involved in the execution of apoptosis and was induced up to 1.5-fold even at low concentrations of QH (5 and $10 \mu \mathrm{g} / \mathrm{ml}$ ) (Fig. 2D). At higher concentrations (20 and $30 \mu \mathrm{g} / \mathrm{ml})$, the induction increased up to 2.3-fold. Poly(ADP-ribose) polymerase 1 (PARP-1) is a substrate for caspase-3 cleavage and produces cleaved PARP-1 (19). There was an increase in PARP cleavage when cells were treated with $\mathrm{QH}$, as also shown in the densitometry analysis for PARP-1 cleavage/ $\beta$-actin (Fig. 2E).

Modulation of Spl transcription factors and dependent genes. Previous studies with several botanical anticancer agents and 
A

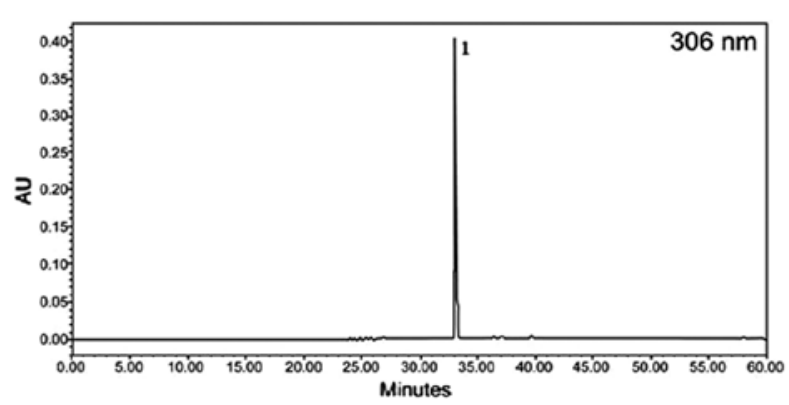

B

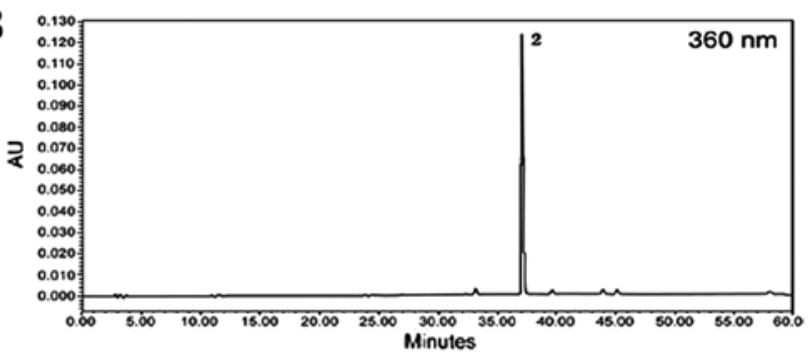

$\mathbf{E}$

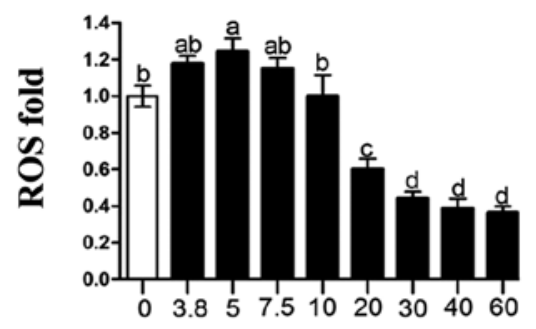

Concentration $(\mu \mathrm{g} / \mathrm{ml}) \mathbf{Q H}$<smiles>COc1cc(O)cc(O)c1C(=O)OC1C(O)C(O)C(O)C1O</smiles><smiles></smiles>

$\mathbf{F}$

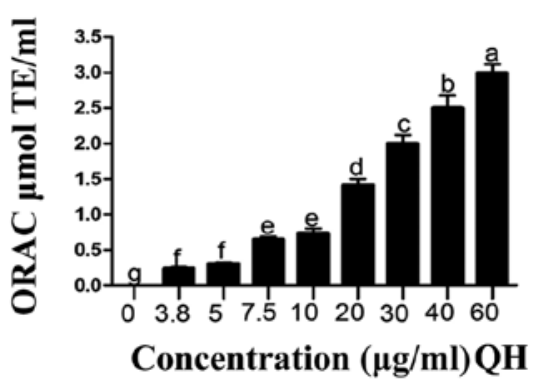

Figure 1. Chromatographic profile of quercetin and hyperoside (QH) in combination. (A) Stilbenes; (B) flavonols. Peak assignments: 1, hyperoside; 2, quercetin. (C) Chemical structure of hyperoside. (D) Chemical structure of quercetin. (E) Hydrogen peroxide-induced generation of reactive oxygen species (ROS) in 786-O cells treated with QH. (F) Oxygen radical absorbance capacity assay (ORAC) values for the 786-O cell supernatant following treatment with QH after $24 \mathrm{~h}$. Bars of the histograms represent mean \pm SEM; $n=3$. Bars with different letters indicate significantly different results (least significant difference test, $\mathrm{p}<0.05)$.

their synthetic derivatives have demonstrated that these compounds downregulate $\mathrm{Sp}$ transcription factors and Sp-regulated genes (20). The present results showed that $\mathrm{QH}$ (5-30 $\mu \mathrm{g} / \mathrm{ml}$ ) decreased Sp1, Sp3 and Sp4 mRNA levels, and there was also a parallel decrease in Sp1, Sp3 and Sp4 proteins (Fig. 3A-C and E). In addition, QH also decreased expression of survivin protein and mRNA, and these results are consistent with QH-mediated suppression of Sp transcription factors since survivin is an $\mathrm{Sp}$-regulated gene. We also carried out densitometry for the $\mathrm{Sp} 1, \mathrm{Sp} 3, \mathrm{Sp} 4$, and Sp-regulated genes, expressed as a ratio to $\beta$-actin (Fig. 3F).

Previous studies have demonstrated that the inhibition of ZBTB10 expression by miR-27a is at least in part responsible for the increased expression of $\mathrm{Sp}$ transcription factors in cancer cells and tumors (21). In the present study, QH significantly decreased miR-27a (Fig. 4A) and upregulated ZBTB10 mRNA (Fig. 4B), and this was accompanied by decreased Sp proteins and the Sp-regulated gene survivin (Fig. 3D and E). These results are consistent with previous studies regarding the effects of other botanicals and their derivatives on the miR-27a-ZBTB10-Sp1 axis in multiple cancer cell lines (21). In this study, the overexpression of the miR-27a mimic in 786-0 cells increased miR-27a, decreased ZBTB10 and increased Sp1 mRNA levels and this was consistent with the inactivation of endogenous ZBTB10 expressed in these cells (Fig. 5A-D). Moreover, the miR-27a mimic also partially reversed $\mathrm{QH}$-induced downregulation of miR-27a, induction of ZBTB10, and downregulation of Sp1 (Fig. 5). Densitometry was performed for Sp-1/ $\beta$-actin (Fig. $5 \mathrm{E}$ ).

\section{Discussion}

Generation of intracellular ROS and ORAC. The generation of ROS has been associated with oxidative cellular damage that may be involved in the development of various pathological conditions (22). The role of ROS in carcinogenesis is complex. Cancer cells tend to have higher constitutive levels of ROS than normal cells, due in part to mutations in nuclear and mitochondrial genes responsible for the electron transport chain and also due to increased metabolism and mitochondrial activity (23). Elevated levels of ROS may enhance cell proliferation and other events relevant to cancer progression (23). ROS can also cause DNA damage and oxidation of fatty acids in cellular membrane structures, thereby facilitating mutagenesis and cancer development (23). However, many anticancer drugs are mitochondro-toxic and induce ROS, which in turn can lead to cancer cell death. Polyphenolics, such as quercetin and hyperoside, have the ability to scavenge free radicals 
A

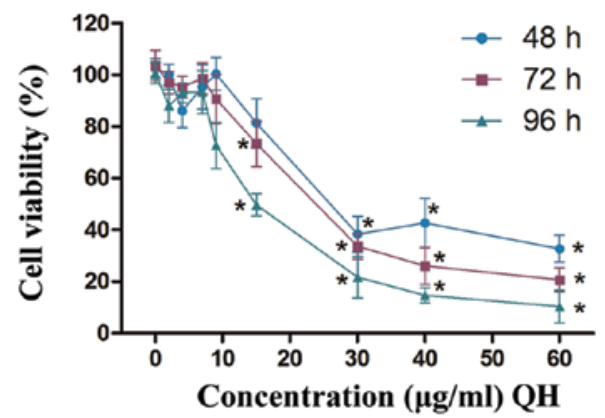

C

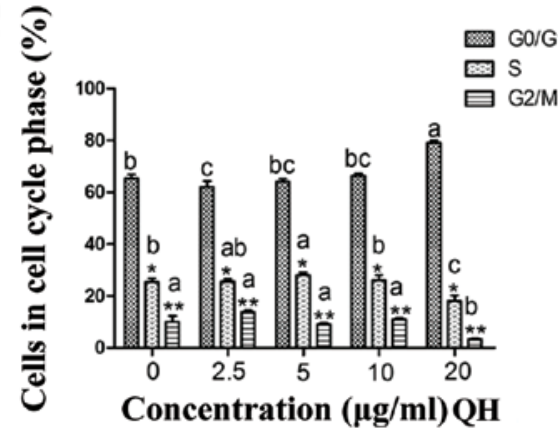

$\mathbf{E}$

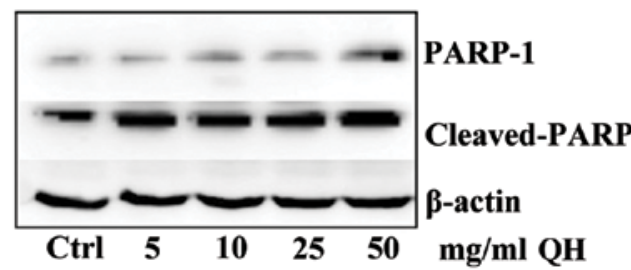

B

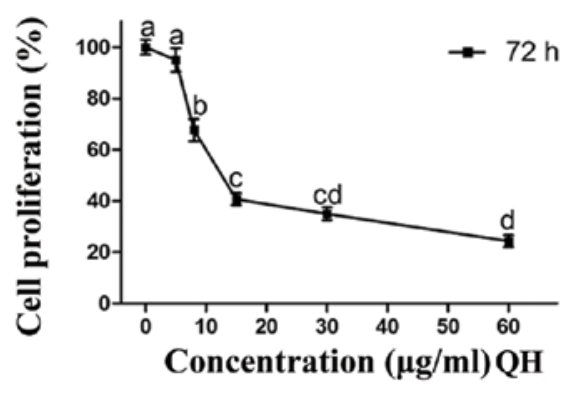

D

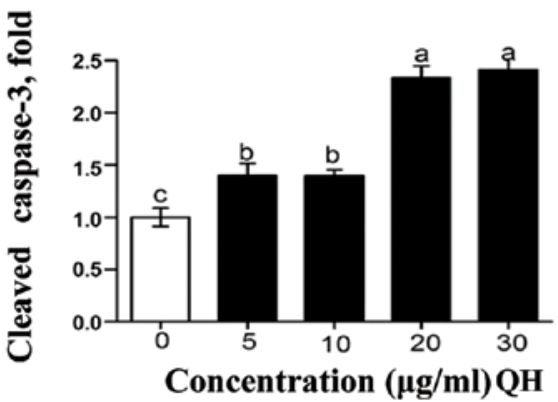

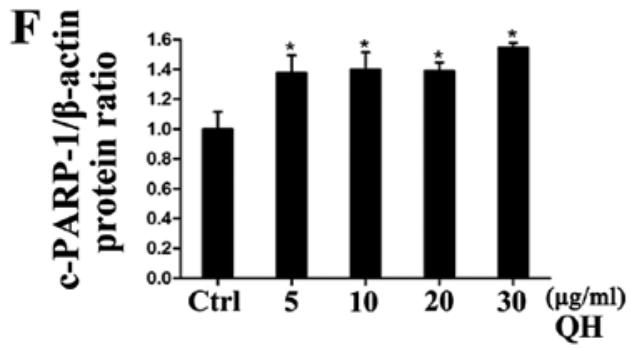

Figure 2. Effects of quercetin and hyperoside $(\mathrm{QH})$ on cell death in 786-O cells. (A) Cell viability of 786-O cells treated with $\mathrm{QH}$ after 48,72 and $96 \mathrm{~h}$ of incubation. (B) Cell proliferation of 786-O cells after $72 \mathrm{~h}$ of incubation. (C) Cell cycle kinetics in 786-O cells treated with the QH mixture for $24 \mathrm{~h}$. (D) Protein levels of cleaved caspase-3 at $24 \mathrm{~h}$. (E) Protein expression of poly(ADP-ribose) polymerase-1 (PARP-1) and cleaved PARP (Asp214) at $24 \mathrm{~h}$ (F) Protein expression of cleaved PARP normalized to $\beta$-actin. Values represent mean \pm SEM; $n=3$. Bars with different letters indicate significantly different results (least significant difference test, $\mathrm{p}<0.05$ ).

and also induce activation of antioxidant and detoxifying enzymes, thus protecting cells against oxidative damage from carcinogenic compounds (24). In this study, $\mathrm{QH}$ induced a concentration-dependent increase in intracellular antioxidant capacity (Fig. 1E) and the intracellular concentration of ROS increased at a low $\mathrm{QH}$ concentration $(5 \mu \mathrm{g} / \mathrm{ml})$ but decreased at high concentrations $(20-60 \mu \mathrm{g} / \mathrm{ml})$ (Fig. 1E). One possible explanation for this biphasic effect may be the mitochondrotoxic properties of polyphenolics, which also induce ROS, whereas at higher concentrations their antioxidant properties are predominant. Studies with polyphenolics in cancer cells demonstrate their protective effects against oxidative damage in some conditions (25). In this study, QH induced ROS at lower concentrations, potentially because of the additional formation of radicals, where $\mathrm{QH}$ concentrations were too low to have a protective effect. At higher concentrations, $\mathrm{QH}$ inhibited the generation of ROS, potentially through scavenging ROS.

Cell death and cell cycle kinetics. The anti-proliferative effects of quercetin and hyperoside were previously demonstrated in
MOLT-4 leukemia cells, and the combination of resveratrol and quercetin exhibited synergistic effects (9). Based on the previous study, a combination of quercetin and hyperoside at a ratio of 1:1 was investigated in the present study, resulting in a significant decrease in cell viability and cell proliferation following treatment with QH (Fig. 2A and B). However, it must be considered that for the chosen cell model, another ratio may have been more effective.

It was previously demonstrated that cell cycle arrest is induced by polyphenolics, including resveratrol and quercetin in several cancer cell lines within different phases (26). Tan et al (27) studied the effect of quercetin on HepG2 cells and found that following treatment with quercetin for $48 \mathrm{~h}$, cells were arrested in the $\mathrm{G}_{0} / \mathrm{G}_{1}$ phase. In MOLT-4 leukemia cells, polyphenolic-mediated cell cycle arrest was influenced by the duration of treatment and the type of polyphenolic. In the present study, QH $(20 \mu \mathrm{g} / \mathrm{ml})$ decreased the percentage of cells in the S-phase and increased the percentage of cells in the $G_{0} / G_{1}$ phase, which is consistent with the inhibition of the progression from $\mathrm{G}_{0} / \mathrm{G}_{1}$ to $\mathrm{S}$-phase (Fig. 2C). 
A

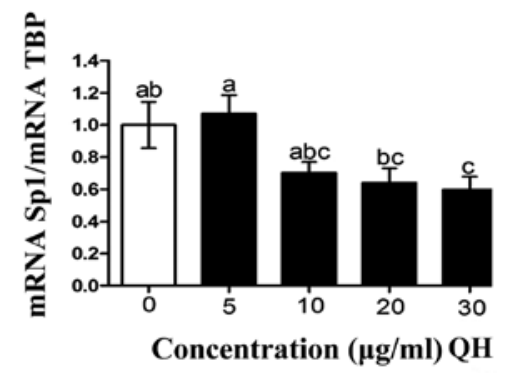

C

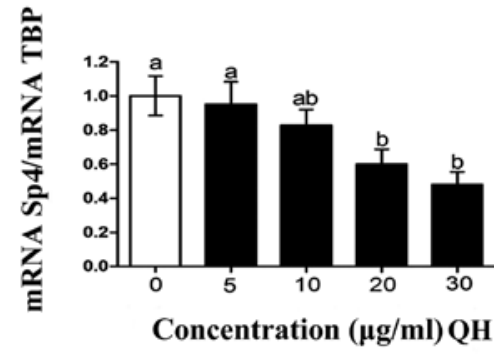

$\mathbf{E}$

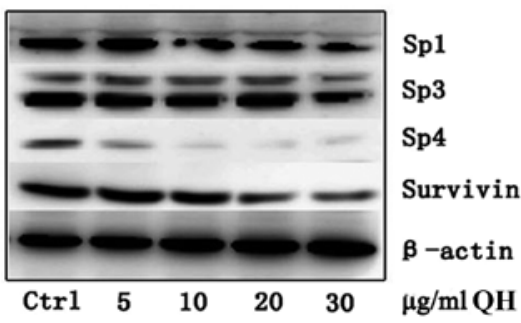

B

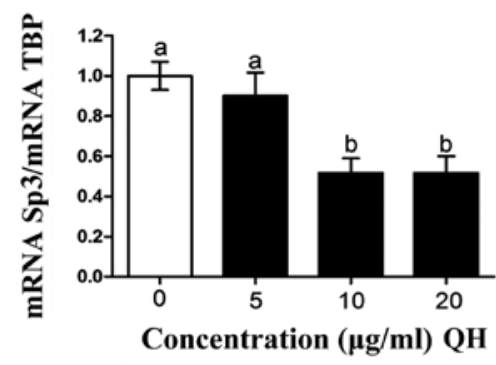

D
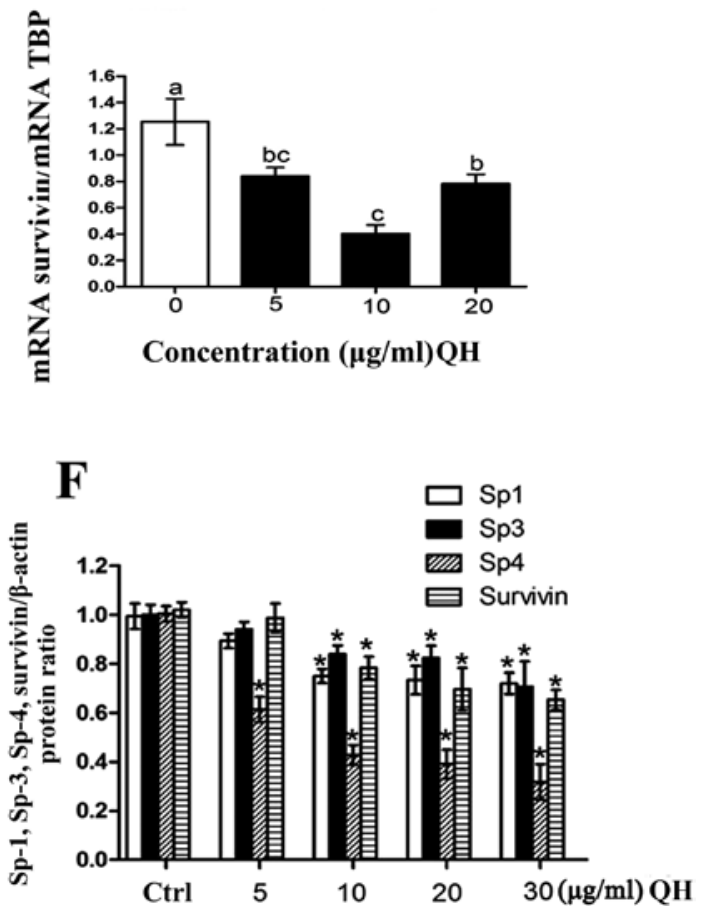

Figure 3. Expression of specificity protein ( $\mathrm{Sp}) 1, \mathrm{Sp} 3, \mathrm{Sp} 4$ and survivin in 786-O cells after $24 \mathrm{~h}$ of incubation with quercetin and hyperoside (QH). (A) $\mathrm{mRNA}$ expression of Sp1. (B) mRNA expression of Sp3. (C) mRNA expression of Sp4. (D) mRNA expression of survivin. (E) Protein expression of Sp proteins and survivin. (F) Protein expression of Sp proteins and survivin normalized to $\beta$-actin. Bars represent mean $\pm \mathrm{SEM}, \mathrm{n}=3$. Bars with different letters indicate significantly different results (least significant difference test, $\mathrm{p}<0.05$ ).
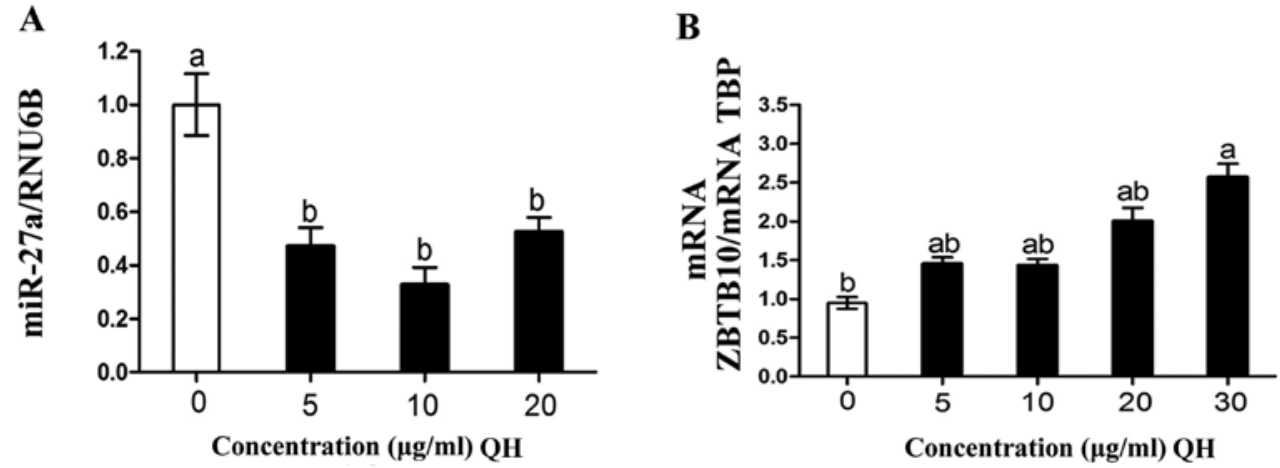

Figure 4. Expression of microRNA-27a (miR-27a) and ZBTB10 in 786-O cells $24 \mathrm{~h}$ after incubation with quercetin and hyperoside (QH). (A) Expression of miR-27a. (B) mRNA expression of ZTB10. Bars represent mean \pm SEM; $n=3$. Bars with different letters indicate significantly different results (least significant difference test, $\mathrm{p}<0.05)$.

Caspase- 3 is a major executive enzyme in apoptosis and a commonly used indicator for the induction of apoptosis (28).
PARP-1, an abundant chromatin-associated protein, plays an important role in maintaining genome integrity and is cleaved 
A

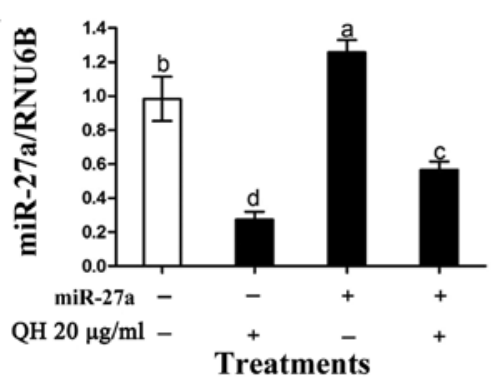

B

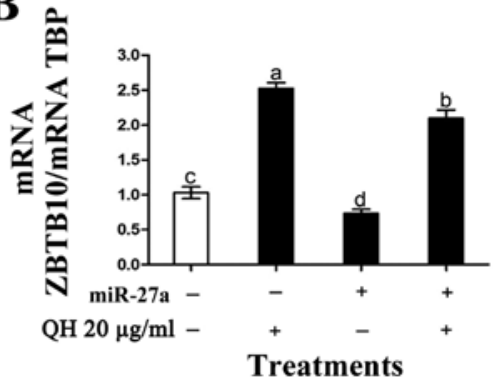

C

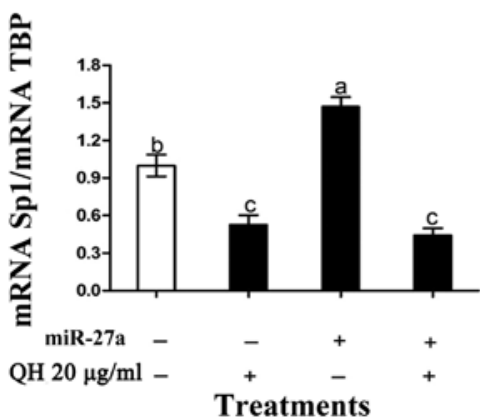

D

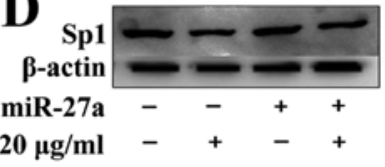

$\mathbf{E}$

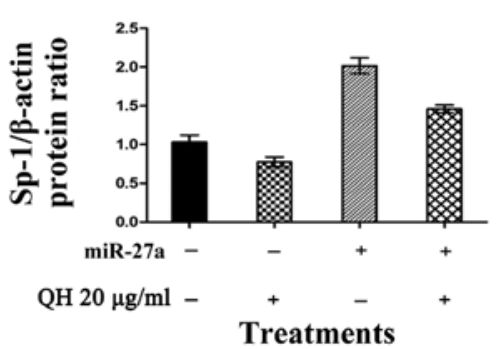

Figure 5. Effects of microRNA-27a (miR-27a) mimic on the miR-27a-ZBTB10-Sp1 axis after 24 h. (A) Expression of miR-27a after transfection with miR-27a mimic in HT-29 cells. (B) mRNA expression of ZBTB10. (C) mRNA expression of specificity protein (Sp)1. (D) Protein expression of Sp1 protein after transfection with miR-27a mimic. (E) Protein expression of Sp1 was normalized to $\beta$-actin. Bars represent means \pm SEM; $n=3$. Bars with different letters indicate significantly different results (least significant difference test, $\mathrm{p}<0.05$ ).

during apoptosis by caspase-3 (29). Previous studies have demonstrated the effects of quercetin, as well as of a number of other polyphenolics, on caspase-3 and PARP-1 activity (30). In general, the findings of this study are in concordance with previous studies that found that polyphenolics induce apoptosis through the activation of caspase- 3 accompanied by cleavage of the DNA repair enzyme poly(ADP-ribose) polymerase (PARP) (28). Previous studies have shown that resveratrol causes induction of caspase-3 and cleavage of PARP in human articular chondrocytes and myeloid leukemia cells (28).

Modulation of Spl transcription factors and dependent genes. Numerous botanical compounds have previously been demonstrated to downregulate $\mathrm{Sp}$ transcription factors and Sp-regulated genes (21). For example, curcumin decreased $\mathrm{Sp} 1, \mathrm{Sp} 3$, and Sp4 levels in bladder and pancreatic cancer cells. The terpenoid betulinic acid also decreased expression of these transcription factors in prostate cancer cells, and synthetic analogs of the triterpenoids oleanolic and glycyrrhetinic acid also exhibited comparable effects (22). The importance of $\mathrm{Sp} 1$ downregulation in terms of the anticancer activity of these compounds is that Sp-regulated genes play an important role in cancer cell and tumor growth (cyclin D1, c-MET and EGFR), survival (NF- $\mathrm{B}-\mathrm{p} 65$, survivin and Bcl-2), and angiogenesis (VEGF and its receptors) (31).

Sp1 overexpression in gastric and pancreatic cancer patients is a negative prognostic factor, as there is evidence that Spl exhibits oncogenic properties and plays a role in cell transformation and maintenance of the cancer phenotype (32).
The pathways associated with the induction of high levels of Sp1, Sp3 and Sp4 during transformation are not known. However, our study indicated that at least one mechanism for their elevated expression in cancer cells and tumors was due to inhibition of ZBTB10 expression by miR-27a. ZBTB10 is a translational repressor and binds GC-rich sites to decrease Sp-dependent trans-activation (33). In the present study, the effects of QH were not dose-dependent for miR-27a itself, but for ZBTB10 (Fig. 4A and B). Many miRNAs play important roles in carcinogenesis, with either oncogenic or tumor-suppressing activities (34). The overexpression of oncogenic miRNAs has been demonstrated in several cancer cell lines (35). In previous studies, miR-27a expression was increased in 6 breast cancer cell lines and also in colon cancer cells $(35,36)$. In the present study, a mimic for miR-27a partially reversed the effects of the extracts on Sp1 protein; however these effects were not significant for Sp1 mRNA.

Results from this study for the first time demonstrated that apoptosis induced by QH and inhibition of HT-29 cell growth was associated with decreased expression of Sp1, Sp3, Sp4, and $\mathrm{Sp}$-regulated survivin. These latter responses were paralleled by perturbation of the miR-27a-ZBTB10 axis, resulting in the induction of ZBTB10, a potent Sp-repressor gene (36). These effects of $\mathrm{QH}$ on miR-27a-ZBTB10 were observed at concentrations of $\mathrm{QH}$ that decreased ROS in the HT-29 cells (Fig. 1E), whereas previous studies with curcumin and the synthetic triterpenoid methyl-2-cyano-3, 12-dioxooleana-1, 9-dien-28-oate (CDDOMe) showed that their effects on miR-27a-ZBTB10 were dependent on the generation of 
ROS (36). Ongoing studies in our laboratory are focused on mechanisms of ROS-independent downregulation of miR-27a by $\mathrm{QH}$ and other anticancer agents as this pathway plays an important role in the anticancer activity of botanicals and their derivates.

In conclusion, the present results revealed that a combination of quercetin and hyperoside had cytotoxic effects on colon cancer cells, resulting in apoptosis. Interactions of QH and the miR-27a-ZBTB10-Sp1 axis were identified as one possible underlying mechanism. Further studies are needed to assess the role of miR-27a and its clinical relevance in the anticancer effects exhibited by botanicals.

\section{Acknowledgements}

This study was partially supported by grants from the National Natural Science Foundation of China (nos. 81000311 and 81270831).

\section{References}

1. Miyamoto H, Miller JS, Fajardo DA, et al: Non-invasive papillary urothelial neoplasms: the $2004 \mathrm{WHO} / \mathrm{ISUP}$ classification system. Pathol Int 60: 1-8, 2010

2. Zisman A, Pantuck AJ, Wieder J, et al: Risk group assessment and clinical outcome algorithm to predict the natural history of patients with surgically resected renal cell carcinoma. J Clin Oncol 20: 4559-4566, 2002.

3. Eble JN, Sauter G, Epstein JI and Sesterhenn I (eds): World Health Organization Classification of Tumors. Pathology and Genetics of Tumors of the Urinary System and Male Genital Organs. IARC Press, Lyon, 2005.

4. Theodoratou E, Kyle J, Cetnarskyj R, et al: Dietary flavonoids and the risk of colorectal cancer. Cancer Epidemiol Biomarkers Prev 16: 684-693, 2007.

5. Kim MJ, Kim YJ, Park HJ, et al: Apoptotic effect of red wine polyphenols on human colon cancer SNU-C4 cells. Food Chem Toxicol 44: 898-902, 2006.

6. Mertens-Talcott SU and Percival SS: Ellagic acid and quercetin interact synergistically with resveratrol in the induction of apoptosis and cause transient cell cycle arrest in human leukemia cells. Cancer Lett 218: 141-151, 2005.

7. Chu CY, Lee HJ, Chu CY, et al: Protective effects of leaf extract of Zanthoxylum ailanthoides on oxidation of low-density lipoprotein and accumulation of lipid in differentiated THP-1 cells Food Chem Toxicol 47: 1265-1271, 2009.

8. Gao LL, Feng L, Yao ST, et al: Molecular mechanisms of celery seed extract induced apoptosis via $\mathrm{S}$ phase cell cycle arrest in the BGC-823 human stomach cancer cell line. Asian Pac J Cancer Prev 12: 2601-2606, 2011.

9. Mertens-Talcott SU, Talcott ST and Percival SS: Low concentrations of quercetin and ellagic acid synergistically influence proliferation, cytotoxicity and apoptosis in MOLT-4 human leukemia cells. J Nutr 133: 2669-2674, 2003.

10. George J, Singh M, Srivastava AK, et al: Resveratrol and black tea polyphenol combination synergistically suppress mouse skin tumors growth by inhibition of activated MAPKs and p53. PLoS One 6: e23395, 2011.

11. Srivastava RK, Tang SN, Zhu W, et al: Sulforaphane synergizes with quercetin to inhibit self-renewal capacity of pancreatic cancer stem cells. Front Biosci (Elite Ed) 3: 515-528, 2011.

12. Tang SN, Singh C, Nall D, et al: The dietary bioflavonoid quercetin synergizes with epigallocatechin gallate (EGCG) to inhibit prostate cancer stem cell characteristics, invasion, migration and epithelial-mesenchymal transition. J Mol Signal 5: 14,2010

13. Chadalapaka G, Jutooru I, Burghardt R and Safe S: Drugs that target specificity proteins downregulate epidermal growth factor receptor in bladder cancer cells. Mol Cancer Res 8: 739-750, 2010.

14. Chadalapaka G, Jutooru I, Chintharlapalli S, et al: Curcumin decreases specificity protein expression in bladder cancer cells. Cancer Res 68: 5345-5354, 2008.
15. Chintharlapalli S, Papineni S, Abdelrahim M, et al: Oncogenic microRNA-27a is a target for anticancer agent methyl 2-cyano3,11-dioxo-18ß-olean-1,12-dien-30-oate in colon cancer cells. Int J Cancer 125: 1965-1974, 2009.

16. Jutooru I, Chadalapaka G, Abdelrahim M, et al: Methyl 2-cyano3,12-dioxooleana-1,9-dien-28-oate decreases specificity protein transcription factors and inhibits pancreatic tumor growth: role of microRNA-27a. Mol Pharmacol 78: 226-236, 2010.

17. Jutooru I, Chadalapaka G, Lei P and Safe S: Inhibition of NF- $\kappa B$ and pancreatic cancer cell and tumor growth by curcumin is dependent on specificity protein down-regulation. J Biol Chem 285: 25332-25344, 2011.

18. Frémont L: Biological effects of resveratrol (Review). Life Sci 66: 663-673, 2000

19. Brauns SC, Dealtry G, Milne P, et al: Caspase- 3 activation and induction of PARP cleavage by cyclic dipeptide Cyclo(Phe-Pro) in HT-29 cells. Anticancer Res 25: 4197-4202, 2005.

20. Meng Q, Velalar CN and Ruan R: Effects of epigallocatechin3-gallate on mitochondrial integrity and antioxidative enzyme activity in the aging process of human fibroblast. Free Rad Biol Med 44: 1032-1041, 2008.

21. Mertens-Talcott SU, Chintharlapalli S, Li MR and Safe S: The oncogenic microRNA-27a targets genes that regulate specificity protein transcription factors and the $\mathrm{G}_{2}-\mathrm{M}$ checkpoint in MDA-MB-231 breast cancer cells. Cancer Res 67: 11001-11011, 2007.

22. Fresco P, Borges F, Diniz C and Marques MP: New insights on the anticancer properties of dietary polyphenols. Med Res Rev 26: 747-766, 2006

23. Schumacker PT: Reactive oxygen species in cancer cells: live by the sword, die by the sword. Cancer Cell 10: 175-176, 2006.

24. Fiander $\mathrm{H}$ and Schneider H: Dietary ortho phenols that induce glutathione S-transferase and increase the resistance of cells to hydrogen peroxide are potential cancer chemopreventives that act by two mechanisms: the alleviation of oxidative stress and the detoxification of mutagenic xenobiotics. Cancer Lett 156: $117-124,2000$.

25. Hsu SC, Lu JH, Kuo CL, et al: Crude extracts of Solanum lyratum induced cytotoxicity and apoptosis in a human colon adenocarcinoma cell line (colo 205). Anticancer Res 28: 1045-1054, 2008.

26. SchlachtermanA, Valle F, Wall KM, et al: Combined resveratrol, quercetin, and catechin treatment reduces breast tumor growth in a nude mouse model. Transl Oncol 1: 19-27, 2008.

27. Tan J, Wang B and Zhu L: Regulation of survivin and Bcl-2 in HepG 2 cell apoptosis induced by quercetin. Chem Biodivers 6 : 1101-1110, 2009.

28. Shakibaei M, John T, Seifarth C and Mobasheri A: Resveratrol inhibits IL- $1 \beta$-induced stimulation of caspase- 3 and cleavage of PARP in human articular chondrocytes in vitro. Ann NY Acad Sci 1095: 554-563, 2007.

29. Wang ZQ, Stingl L, Morrison C, et al: PARP is important for genomic stability but dispensable in apoptosis. Genes Dev 11: 2347-2358, 1997.

30. Hsu CP, Lin YH, Chou CC, et al: Mechanisms of grape seed procyanidin-induced apoptosis in colorectal carcinoma cells. Anticancer Res 29: 283-289, 2009.

31. Lee HS, Park CK, Oh E, et al: Low SP1 expression differentially affects intestinal-type compared with diffuse-type gastric adenocarcinoma. PLoS One 8: e55522, 2013.

32. Deacon K, Onion D, Kumari R, et al: Elevated SP-1 transcription factor expression and activity drives basal and hypoxia-induced vascular endothelial growth factor (VEGF) expression in non-small cell lung cancer. J Biol Chem 287: 39967-39981, 2012.

33. Kim K, Chadalapaka G, Lee SO, et al: Identification of oncogenic microRNA-17-92/ZBTB4/specificity protein axis in breast cancer. Oncogene 31: 1034-1044, 2012.

34. Lynam-Lennon N, Maher SG and Reynolds JV: The roles of microRNA in cancer and apoptosis (Review). Biol Rev Camb Philos Soc 84: 55-71, 2009.

35. Tang W, Zhu J, Su S, et al: MiR-27 as a prognostic marker for breast cancer progression and patient survival. PLoS One 7: e51702, 2012.

36. Noratto GD, Jutooru I, Safe S, et al: The drug resistance suppression induced by curcuminoids in colon cancer SW-480 cells is mediated by reactive oxygen species-induced disruption of the microRNA-27a-ZBTB10-Sp axis. Mol Nutr Food Res 57: 1638-1648, 2013. 